\title{
Immunotherapy for West Nile virus infection
}

The treatment for infection by West Nile virus (WNV) is currently supportive. New research, however, suggests that a monoclonal antibody may the future. ${ }^{1}$

WNV is a single-stranded RNA flavivirus related to the viruses that cause yellow and dengue fever. The first outbreak of WNV infection in North America occurred in New York in 1999, and it appeared in Ontario in 2001. About $80 \%$ of infected people remain asymptomatic, 20\% experience a febrile illness and about $1 \%$ experience severe neurologic disease. ${ }^{2}$ prove an effective treatment in

Human immunoglobulin has been touted as a potential treatment for WNV infection, but problems with loss of effectiveness over time ${ }^{3}$ and variability in production limit its use. ${ }^{1} \mathrm{Re}$ cently, Theodore Oliphant and colleagues developed a monoclonal antibody specific to WNV to overcome these challenges. Targeting a protein on the viral envelope, they demonstrated that one particular antibody, E16, blocked infection of cells by 10 different strains of WNV in vitro, including the original lineage II strain that was isolated in 1937. The researchers then showed that the

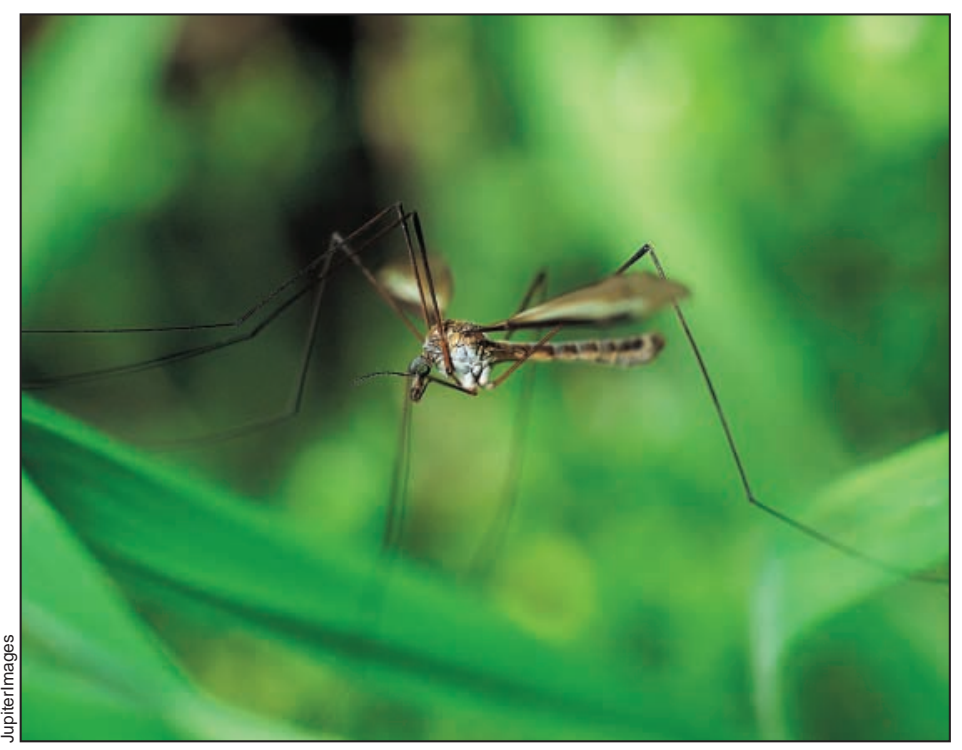

antibody protected mice known to be susceptible to WNV infection, increasing their survival rate after infection from $10 \%$ to $90 \%$. Improved survival occurred when the antibody was administered after infection was established (2 days after inoculation with the virus) and when it was administered after infection was established in the central nervous system (5 days after inoculation). ${ }^{1}$

The researchers then looked at adapting E16 for use in humans. Antibodies found in humans who have recovered from WNV infection recognize the same protein targeted by E16. The researchers created a version of E16 on a human antibody backbone that also neutralized the virus. Although the antibody has yet to be tested in clinical trials, it is hoped that this research may result in viable treatment for WNV infection. - David Secko, Vancouver

\section{References}

1. Oliphant T, Engle M, Nybakken GE, Doane C, Johnson S, Huang L, et al. Development of a humanized monoclonal antibody with therapeutic potential against West Nile virus. Nat Med 2005;11(5):522-30.

2. Weir E, Shapiro H. West Nile virus: round five. CMAJ 2004;170(11): 1669-70.

3. Granwehr BP, Lillibridge KM, Higgs S, Mason PW, Aronson JF, Campbell GA, et al. West Nile virus: where are we now? Lancet Infect Dis 2004;4:547-56. 